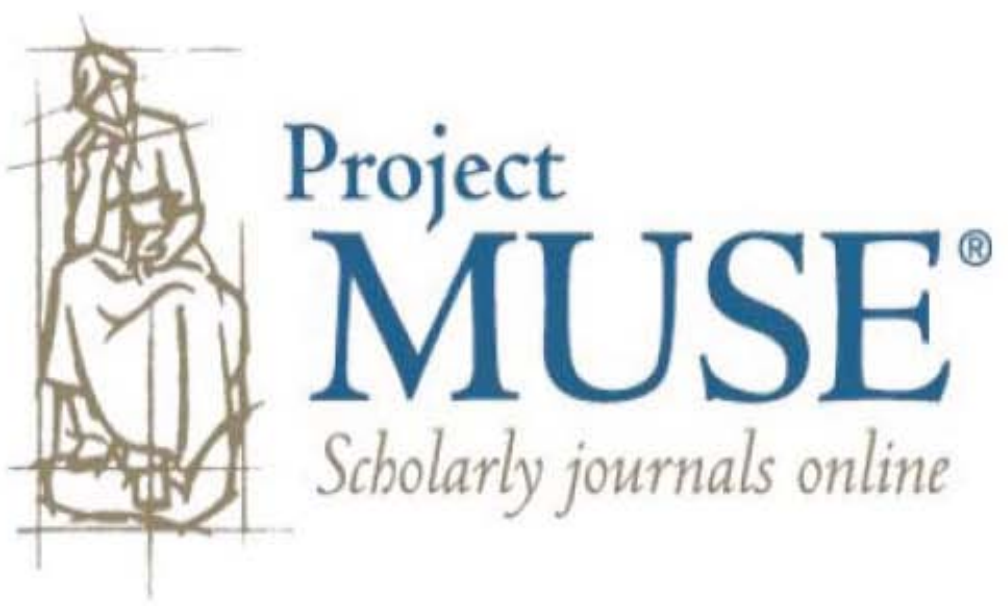




\title{
Another Look at the Marking of Plural Personal Noun Constructions in Austronesian Languages
}

\author{
Lawrence A. Reid \\ UNIVERSITY OF HAWAI'I \\ INTERNATIONAL INSTITUTE FOR ASIAN STUDIES \\ UNIVERSITY OF LEIDEN
}

\begin{abstract}
In a recent note in this journal, Robert Blust, using data from Philippine and Formosan languages, proposes a functional difference for Proto-Austronesian between the forms of genitive common noun phrase markers, such that PAN *nu marked 'genitive of common nouns', while PAN *na marked 'genitive of plural personal nouns'. This paper examines the Philippine and Formosan evidence for these reconstructions and concludes that the evidence provided is the result of convergent development in the languages cited, and cannot be considered evidence for the proposed reconstructions. Alternate reconstructions that better account for the Philippine evidence are proposed.
\end{abstract}

1. INTRODUCTION. ${ }^{1}$ In a note on the reconstruction of Proto-Austronesian genitive markers, Blust (2005:215) states, "Three forms of the genitive phrase marker have been proposed for Proto-Austronesian: *ni, *na, and *nu. While there is universal agreement on the form of this reconstructed system, reconstruction of the meanings/functions of these forms has been far more problematic." He furthermore argues that "**nu marked the genitive of common nouns, while *ni and *na marked the genitive of singular and plural personal nouns respectively." The need to possibly reconstruct *na as a marker associated with plural personal noun phrases was first discussed in Reid (1978:42), ${ }^{2}$ citing much of the same data as used in Blust's note. However, subsequent examination of the evidence has failed to convince me of the adequacy of this reconstruction. The purpose of this paper, then, is to take a closer look at the evidence for distinguishing the marking of plural personal from singular personal noun phrases, and in particular the evidence for *na 'genitive plural personal noun marker', in an attempt to establish whether or not the pro-

I. This paper was first presented at a seminar on the occasion of the retirement of Paul Jen-kuei Li at Academia Sinica, Taipei, Taiwan, Oct. 23, 2006. I have since become aware of Ross 2006, which discusses briefly the Formosan evidence for Blust's reconstruction and concludes, as I have, that the reconstruction is not warranted. I wish to thank two anonymous reviewers for their comments. I cannot, however, hold them accountable for the conclusions I have reached here. For these I take full responsibility. 
posed function is reconstructible to Proto-Austronesian, or is the result of convergent development in some widely separated languages. The following paragraphs constitute the core of Blust's arguments (Blust 2005:2 I8).

a. There is clear evidence, considering only the functions of the forms, and ignoring their cognacy, that in a wide range of Austronesian languages a three-way set of forms occurs, introducing genitive noun phrases that are headed respectively by common nouns, singular personal nouns, and plural personal nouns.

b. While many languages have a two-term system, no language is known that reflects

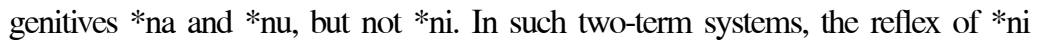
almost always represents the genitive of personal nouns as against another term, a reflex of either *nu or *na, that represents the genitive of common nouns. Languages that reflect all three reconstructed genitive forms are rare. Evidence from those that do is therefore critical, as this enables us to distinguish between the functions of *na and *nu. There are at least two languages that meet this condition.

c. Central Amis, a Formosan language, has a three-way set of genitive forms: $n u$ 'common noun marker', $n i$ 'singular proper noun marker', and $n a$ 'plural proper noun marker', while some of the dialects of Southern Bikol in the Central Philippines, part of a different primary branch of Austronesian, have a "virtually identical system" of genitive marking: $n u$ 'genitive of common nouns, +referential +past', $n i$ 'genitive of persons (singular)', $n a$ 'genitive of persons (plural)'.3 Some other Central Philippine languages such as Bantuanon Bisayan have $n i$ 'genitive singular personal noun' and na 'genitive plural personal nouns', although the genitive common noun marker in Bantuanon is not cognate with Amis and Bikol nu. ${ }^{4}$

d. Ivatan comes very close to matching the evidence from these languages, with no 'genitive of common nouns', $n i$ 'genitive of singular proper nouns', and $d a$ 'genitive of plural proper nouns'. Here the first two terms clearly reflect PAN *nu and *ni with the suggested meanings, but $d a$ either reflects *=da '3PL genitive pronoun', or is a reshaped reflex of PAN *na. ${ }^{5}$

On the surface, these arguments seem convincing, but on careful examination the evidence for them cannot be substantiated. The discussion that follows will focus on the two bodies of evidence that Blust uses to support his reconstructions. In order to evaluate the

2. Here is what was said: "In addition to a distinction between the common noun Det[erminer] and personal noun Det[erminer], there are a number of languages [that] distinguish the marker of a singular from the marking of a plural personal noun. ... Most of the languages accomplish this by replacing the singular marker with a form [that] is identical to the third person plural subject pronoun. Some languages, however, such as Tagalog and Romblon, have added a plural morpheme/-na/ to the singular person marker. This is possibly also the origin of Mamanwa /sin/ ( $<*$ sina), as well as the Aborlan Tagbanwa /na/ [that] replaces the singular Det[erminer] /si/. The use of /na/ as a plural morpheme associated with personal markers, although restricted to a few languages in the Meso-Philippine group, may need to be reconstructed for Proto-Philippines, since it is also attested outside of the Philippines as a plural Genitive marker in Amis."

3. These are similar systems, but are not "virtually identical," because $n u$ only marks genitive common nouns that are '+referential +past'. Genitive common nouns that are nonpast/nonreferential in these dialects are marked by $\operatorname{nin}$ (Jason Lobel pers. comm.).

4. One additional Philippine language that has all three forms is Northern Subanen. The forms that mark ergative (i.e., genitive) common noun phrases are $n ə(<*$ na) and $n u$, where $n u$ optionally introduces common noun phrases that are "anaphoric", while $n i$ introduces ergative personal noun phrases (Daguman 2004:58, I49). 
evidence that is presented in support of a reconstruction it is necessary to look not only at the restricted set of a single case relation, such as genitive, but at the whole system within which the set occurs, because there is clear evidence that analogy and other irregular changes occur that can affect not only the consonantal onset of forms but also their vocalic component as well. ${ }^{6}$ It is necessary also to consider the forms having the same function in related languages as that given for the proposed reconstruction but which do not reflect it, and provide well-motivated explanations for the changes that must have occurred to bring about the innovations. Further evidence can be drawn from the marking of personal pronouns, because these also are typically marked in the same way as personal noun phrases, and often retain frozen case-marking forms that have since been replaced by newer forms. We will first examine the nature of the Philippine evidence in section 2; the Formosan evidence will then be examined in section 3.

2. THE PHILIPPINE EVIDENCE. There is no question that for the parent of the Philippine languages noun phrases that were headed by common nouns were marked differently from those that were headed by personal nouns, regardless of the case relation of the phrase. But whether plural personal noun phrases were marked differently from singular personal noun phrases, and if so, how, is at issue. For the parent of the Philippine languages, it is necessary to reconstruct at least a three-way set of forms that introduce genitive noun phrases. Many Philippine languages also have more than one form introducing genitive common noun phrases, but these will not be further addressed in this paper. The primary question addressed here is what the forms were that distinguished singular personal noun phrases from plural personal noun phrases. ${ }^{7}$

2.1 THE CENTRAL PHILIPPINE LANGUAGES. Considering first the Philippine evidence that Blust has presented for *na 'genitive plural personal noun marker', it might appear that commuting as it does with the other *n-initial genitive forms, *nu and

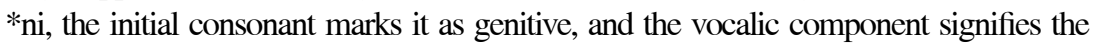
semantic feature of 'plural personal noun' ${ }^{8}$ But when we consider the distribution of the plural personal noun forms in Central Philippine languages, apart from the Southern Bikol dialects that Blust cites, we find that many of the languages combine $n a$ with the form that marks 'singular personal noun' regardless of its case-marking (see table I).

If the Bisayan languages that show na 'genitive plural personal noun' directly reflect a PAN *na with the same meaning, then an explanation is needed for the pres-

5. Language name abbreviations used in this paper are the following: AKL, Aklanon; AmI, Amis; BAN, Bantayan; BLK, Bulaloknon; BoH, Boholano; But, Butuanon; CAP, Capiznon; CEB, Cebuano; DsP, Dispoholnon; DTG, Datagnon; Gub, Gubat (South Sorsogon); HiL, Hiligaynon (Ilonggo); JAU, Jaun-jaun; KAV, Kavalan; KIN, Kinaray-a; KUY, Kuyonon; LeY, Leyte; LoK, Looknon; Mas, Masbate; N-S, Northern Samar; OdG, Odianganon; PAN, Proto-Austronesian; PAN, Pandan; PCPH, Proto-Central Philippines; Rom, Romblomanon; Sem, Semirara; Sib, Sibale; S-L, Samar-Leyte; SNT, Santa Teresa; Sor, Sorsogonon; Sur, Surigaonon; TsG, Tausug; WAR, Waray.

6. See Reid (2006, to appear a).

7. In order to focus the discussion on the form of the markers that introduce noun phrases in Philippine languages and their distribution, I will not address problems related to their syntactic category, problems that have been addressed in Reid (2002, to appear a).

8. This is the analysis presented by various scholars of the equivalent set of forms in Amis, such as Liu (1999:35) and $\mathrm{Wu}$ (2006:79), and is the analysis that Ross (2006) adopts. 
ence of na as part of a series of complex forms that occurs not only in genitive noun phrases but also in unmarked and locative noun phrases in three different Central Philippine subgroups, Tagalog, Bikol, and Bisayan, as well as some of the other languages of the Meso-Philippine group.

The only hypotheses available are that: (I) *na spread independently to the unmarked and locative forms that show, respectively, si=na and $k i=n a$, creating disyllabic forms in place of monosyllabic forms, and that: (2) *ni spread from the genitive singular to the plural form of those languages that show ni=na. The alternative is to consider that for Proto-Central Philippines at least, *na did not commute with *ni, but was a noncasemarked plural form, attaching to the singular forms of the markers of nominative, genitive, and locative phrases to create corresponding plural forms. This accounts for the limited data of table I, but as we shall ultimately see, is not an adequate hypothesis either.

A question that needs to be asked, given the possibility that languages such as Tagalog, Romblomanon, and Sibale (in the first three rows of table I) reflect a Proto-Central Philippine set of plural personal noun markers (with stress on the final syllable), *si=ná, *ni=ná, and *kay=ná ( $>* * k i=n a ́),{ }^{9}$ is how can one account for the plural forms in the languages in the other rows of table $\mathrm{I}$ ?

Let us first consider the unmarked personal plural form $s a$. Reflexes of *sa occur widely as the locative marker for common noun phrases expressing future time in Central Philippine languages. One could assume the unlikely proposition that it spread to also introduce unmarked, personal plural phrases. However, one or the other of two alternate hypotheses is far more likely. One hypothesis is that there was analogical pressure toward a canonical CV structure for the plural forms based on the structure of the equivalent singular forms. This is a hypothesis that also accounts for the alternation in Ivatan between the third person plural pronouns sira and $s a$, to be discussed further below.

TABLE 1. PERSONAL NOUN PHRASE MARKERS IN SOME CENTRAL PHILIPPINE LANGUAGES ${ }^{\dagger}$

\begin{tabular}{cllllll} 
& \multicolumn{2}{c}{ UNMARKED $^{\ddagger}$} & & GENITIVE & & \multicolumn{2}{c}{ OBLIQUE/LOCATIVE } \\
& SINGULAR & PLURAL & SINGULAR & PLURAL & SINGULAR & PLURAL \\
Tagalog & si & siná & ni & niná & kay & kiná \\
Bisayan Rom & si & siná & ni & niná & kay & kiná \\
SIB & si & sína & ni & nína & kan & kína \\
BAN, OdG & si & sa & ni & na & kay & kaná \\
Bikol, Naga & si & sa & ni & na & ki & ka \\
Tagbanwa, Aborlan & si & na & ni & na & ki & kana \\
Mamanwa & si & sin & ni & nin & kan & -
\end{tabular}

$\uparrow \quad$ Adapted from Schachter and Otanes (I972:I I3), Mintz (I97I:I03), Zorc (I977:82), Hussey (1966:35), and Miller and Miller (1976:27, 29).

\$ Zorc refers to the functions of these forms as nominative, genitive, and oblique. My preferred terminology for his "nominative" forms is "unmarked," because they introduce NPs that are not morphologically case-marked, but whose word order identifies them as either nominative, predicative, or topic.

9. This hypothesis could account for the loss of the initial syllables in the Aborlan Tagbanwa plural unmarked and genitive plural personal noun forms, as well as the Mamanwa forms $\sin$ and $\operatorname{nin}$ (by stress shift followed by erosion of the final vowel). Under this hypothesis, Sibale would have exhibited a stress shift from that of the proposed reconstruction. 
An alternate hypothesis, given the widespread occurrence of the infix <in $>$ in verbs and nouns, is that *si=ná was perceived as being infixed $*^{*} \mathrm{~s}<\mathrm{in}>$ á, and that it was subsequently reduced to $s a$. Precisely the same pattern of reduction would have resulted in genitive *ni=ná being reanalyzed as $* *$ n<in>á, with subsequent reduction to $n a$. *ka is also reconstructible as a marker of oblique and locative singular personal noun phrases, and one could suggest the possibility that it spread to also mark plural personal noun phrases, as in Naga Bikol. However, given the patterns of reduction noted above, it seems more likely that locative $* * \mathrm{ki}=$ ná was reanalyzed as $* * * \mathrm{k}<\mathrm{in}>\mathrm{a}$, and subsequently became $k a$. In Bantuanon and Odionganon, however, an analogical process operated to change $* * \mathrm{ki}=\mathrm{na}$ to **ka=na, giving $a$-vowels across the set of personal plural forms ( $s a, n a, k a n a ́)$, and removing the possibility of it being perceived as having an infixed $<$ in $>$ (Reid to appear a).

Considering now the forms that mark plural personal noun phrases in some of the Central Philippine languages not shown in table I, the reconstruction of PCPH *si=ná, *ni=ná, and *kay=ná ( $>* * k i=n a ́)$, becomes questionable. Fortunately, Zorc (I977:82) provides us with a comprehensive set of forms from some thirty different Bisayan dialects (table 2), and furthermore provides a subgrouping tree (figure I), based on shared innovations by which we can evaluate the evidence provided us.

\section{TABLE 2. PERSONAL NOUN PHRASE MARKERS IN THE BISAYAN DIALECTS ${ }^{\dagger}$}

\begin{tabular}{|c|c|c|c|}
\hline SINGULAR & UNMARKED & GENITIVE & $\begin{array}{l}\text { OBLIQUE } \\
\text { /LOCATIVE }\end{array}$ \\
\hline TsG & hi & hi & kan \\
\hline WAR & hi & ni & kan \\
\hline MAS, SOR, GUB, N-S, S-L, JAU & si & ni & kan \\
\hline Ban, Odg, Sib, Ceb, BoH, But & si & ni & kay \\
\hline AKL, DsP, LoK, PAN, Kin, BlK, SNT, SEM, Hil, CAP, SuR & si & ni & kay \\
\hline KUY, DTG & si & ni & $\mathrm{ki}$ \\
\hline \multicolumn{4}{|l|}{ PLURAL } \\
\hline TsG & hinda & hinda & kanda \\
\hline MAS & sínda & nínda & kánda \\
\hline SOR, GuB, N-S & sirá & nírá & kánda \\
\hline S-L & sirá & níra & kánda \\
\hline WAR & hirá & níra & kánda \\
\hline But & silá & níla & kánda \\
\hline KUY & sanda & nanda & kanda \\
\hline DTG & sánda & nánda & kanánda \\
\hline AKL, DSP, LOK, PAN, KIN, BlK, SNT, SEM, CAP & sánday & nánday & kánday \\
\hline BoH, Sur & síla & níla & kaníla \\
\hline CEB, LEY & silán & nílā & sa-Rílay \\
\hline CEB & silá-si & níla-ni & sa-Píla-ni \\
\hline HIL & silá-ni & níla-ni & sa-?íla-ni \\
\hline $\mathrm{J}_{\mathrm{AU}}$ & síla-si & níla-ni & díla-ni \\
\hline RoM & siná & niná & kiná \\
\hline SIB & sína & nína & kína \\
\hline BAN, ODG & sa & na & kaná \\
\hline
\end{tabular}

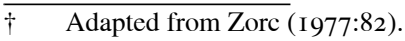


A glance at the data in table 2 shows that the genitive plural personal form $n a$ is found in only two closely related dialects of the Banton branch of Bisayan. Reflexes of the proposed reconstruction *ni=ná are found only in Sibale (with shifted stress), the third dialect of the Banton branch, and in the geographically contiguous Romblomanon (see figure 2). In all other Bisayan dialects, unmarked plural personal noun markers are derivable from a reconstructed *si=dá 'unmarked 3rd person plural pronoun', while genitive forms are derivable from a reconstructed *ni=dá 'genitive 3rd person plural pronoun', and locative forms from one of the locative prepositions, *ka, *sa, or *di plus a cliticized third person plural pronoun, as either *ka=n(i)dá, *sa=?ída, or *di=da. Three languages (Cebuano, Hiligaynon, and Jaun-Jaun) representing three of Zorc's five discrete subgroups of Bisayan, follow these forms by either an unmarked (or in the case

\section{FIGURE 1. GENETIC RELATIONSHIPS OF THE BISAYAN DIALECTS ${ }^{\dagger}$}

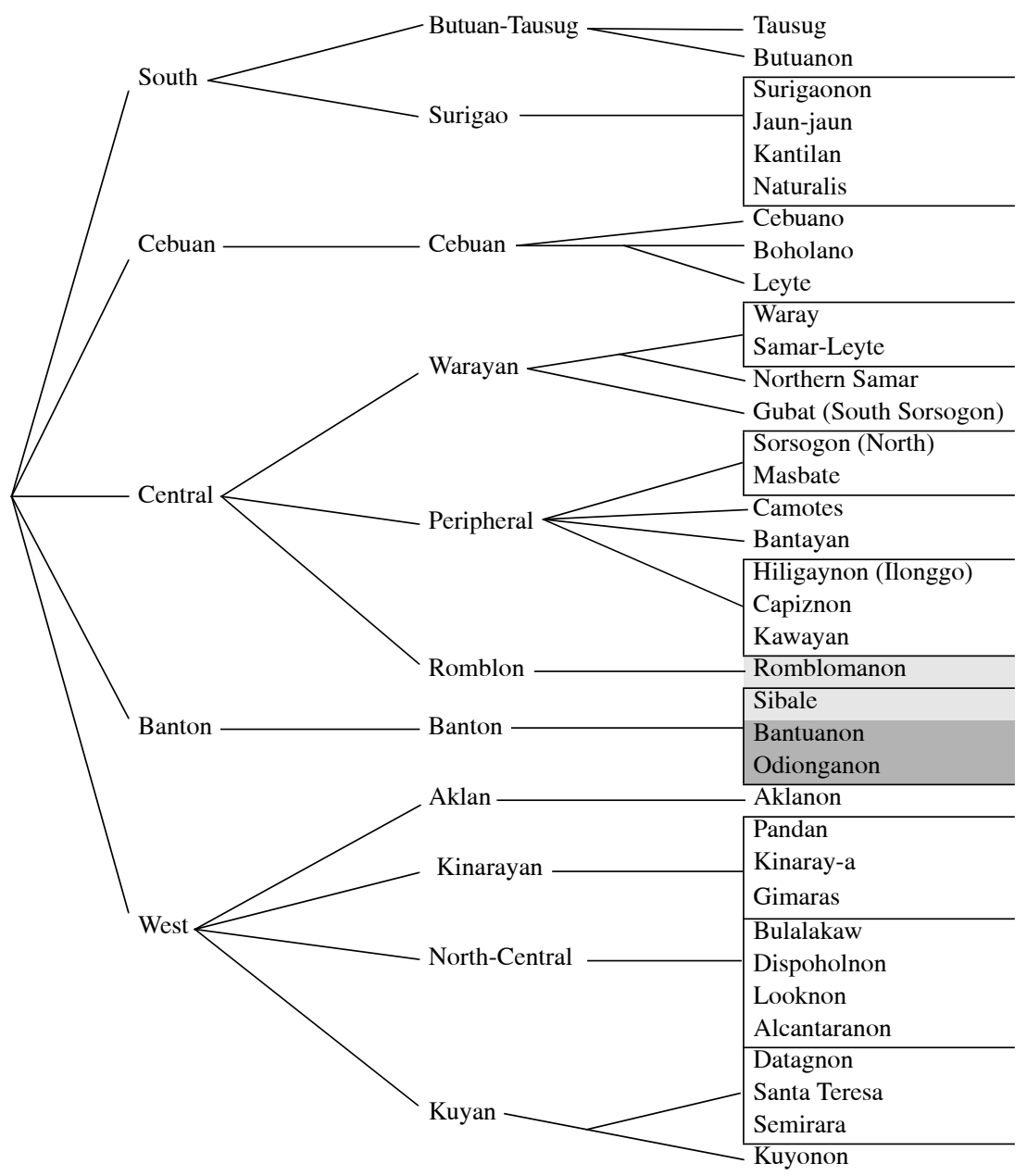

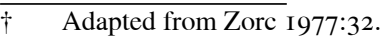


of Jaun-Jaun, a genitive) singular personal noun marker (sila=si, nila=ni), suggesting that these constructions were originally free-form third person plural pronouns concatenated with a personal noun phrase, specifying the name of some individual, either alone, or expanded by a concomitant phrase literally meaning, for example "they, Juan (with

FIGURE 2. POSITION OF THE BANTON AND ROMBLON DIALECTS ${ }^{\dagger}$

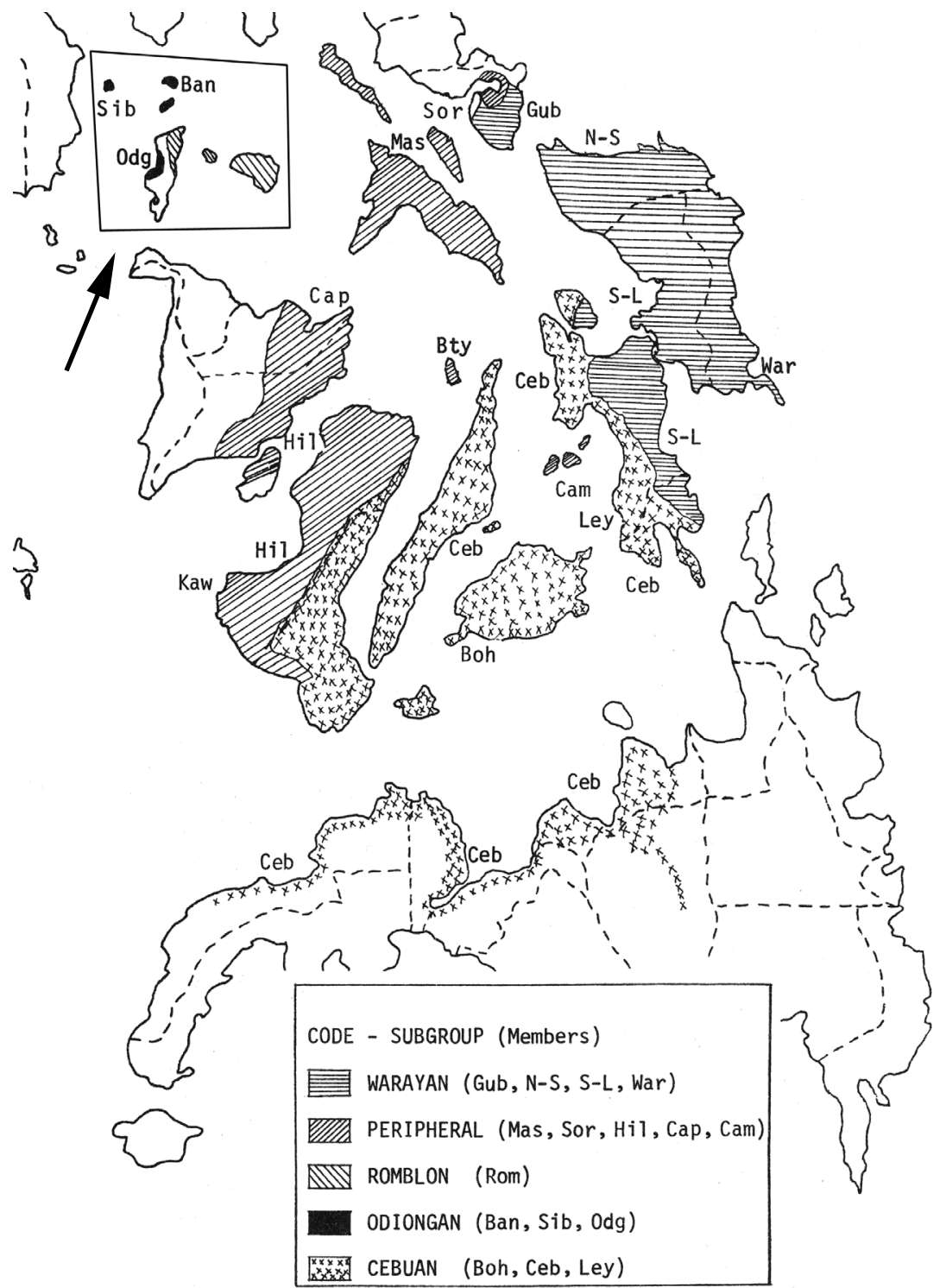

$\overline{\dagger \quad \text { Adapted from Zorc }}$ 1977:I7. 
others)", or "they, Juan with Maria", when the accompanying individual(s) needed to be made explicit. A similar construction occurs in the Buhi dialect of Bikol, sirá si (Yamada and Tsuchida I975:54).

\subsection{RECONSTRUCTION POSSIBILITIES FOR PROTO-CENTRAL}

PHILIPPINES. Considering the sets of data given in tables I and 2, we must now ask the question, which of the various possibly reconstructible forms for introducing unmarked and genitive plural personal noun phrases can best be supported? I0 $^{\text {Io }}$ The options outlined above for Proto-Central Philippines are: (a) *_, ${ }^{\text {II }} *$ na, a direct reflex of PAN *na 'genitive plural personal noun marker' (see 2.2.I); (b) *si=ná, *ni=ná (see 2.2.2); and (c) *si=dá, *ni=dá (third person plural pronoun forms that could be followed by a concatenated personal noun phrase, i.e., *si=dá + *si NP and *ni=dá + *ni NP [see 2.2.3]). ${ }^{12}$ Whichever reconstruction one chooses, a series of convergent developments must have occurred. ${ }^{13}$

2.2.1 PCPH *na (<PAN *na) 'genitive plural personal noun marker'. The most problematic of the possible reconstructions, considering the Philippine data, is the first of the above options, that proposed by Blust. An unchanged reflex of this reconstruction is found only within two closely related Bisayan dialects (Bantuanon and Odiongan), and in a dialect of geographically close Naga Bikol (and in the Palawanic language Aborlan Tagbanwa, where it also introduces unmarked personal plural noun phrases). All other dialects of Bisayan, and Bikol, as well as all other Central Philippine languages, and at least the parent language of each of the other Philippine subgroups, would have innovated a different form for this function.

\subsubsection{PCPH *si=ná, *ni=ná 'UNM and GEN plural personal noun markers'.} The second option, in which plural personal noun phrases were formed by the addition of a pluralizing clitic *=na, regardless of the case of the noun phrase, has better support. The distribution of forms that can possibly be derived from such constructions would include those cited by Blust for his reconstruction, as well as Romblomanon and Sibale (the last three rows of table 2), but which, at best, represent only two of Zorc's five branches of Bisayan, all of which are geographically close to one another. Other possible support comes from two other Central Philippine branches, Tagalog and Mamanwa, geographically distant from the Bisayan dialects cited above, as well as the Palawanic language, Aborlan Tagbanwa.

IO. The various possible reconstructions for the marking of locative phrases will not be discussed further here because of space limitations.

I I. Blust does not attempt a reconstruction of the form that would have introduced unmarked personal plural phrases in Proto-Austronesian.

I 2. Abbreviations used in this paper that are not included in the Leipzig list are the following: NP; noun phrase; SPEC, specifier; and UNM, unmarked.

I3. Blust (2005:2 I8) claims, "If the meanings were *na 'genitive of present common nouns', *nu 'genitive of absent common nouns', *ni 'genitive of personal nouns' as Ross (2002) proposes, it would be necessary to conclude that the attested meanings associated with reflexes of the first two terms are products of convergent innovation in Central Amis and Southern Bikol. While this is not impossible, it is less likely than the contrary hypothesis that *na marked the plural of personal nouns, and that *nu marked common nouns without further distinction, because the latter reconstruction requires no assumption of convergent association between sound and meaning." But it does require an assumption of innovative changes and convergent development in a wide range of languages that do not reflect the meaning-form associations reconstructed by Blust. 


\subsubsection{PCPH si=dá + *si, *ni=dá + *ni 'UNM and GEN plural personal noun} marking'. The third option, in which a reflex of a reconstructible third person plural pronoun, followed by a concatenated personal noun phrase introduced by either *si (unmarked) or *ni (genitive), has the widest support. The distribution of forms that can be derived from such constructions is widespread throughout the Philippines. While there are only three Bisayan dialects that directly reflect the full reconstructed form, other Philippine languages (including Buhi Bikol, as noted above) also do. The most common innovation that has occurred is direct concatenation of the personal noun phrase to the preceding pronoun, without use of any intervening marker, that is, where *si=dá + *si NP and *ni=dá + *ni NP became, respectively, ${ }^{* *}$ sidá NP and ${ }^{* *}$ nidá NP, accounting for the wide range of Bisayan and Bikol dialects with reflexes of these forms. These are also assumed to be the source of the Tagalog, Romblomanon, and Sibale forms sina and nina, as follows.

Tagalog, some dialects of Bikol such as Southern Catanduanes, and a number of Bisayan dialects such as Cebuano, Hiligaynon, Camotes, and Tausug (Zorc I977:75) have undergone a sound change by which the pronouns *sidá and *nidá became respectively sila and nila with medial $l$. The same change may have occurred also in Romblomanon and Sibale; however, subsequent innovations in these dialects have obscured the earlier forms. The innovation by which **sila and **nila have become plural personal NP markers sina and nina requires only an irregular, but not uncommon *1 $>n$ sound change. Loss of the reflex of the unstressed initial syllables of the full forms of the pronouns *sidá and *nidá has created a single CV plural phrase marker $d a$, which commutes with the singular personal NP markers si or $n i$ in many other languages. These innovations are displayed in figure 3 .

It has been suggested in Reid and Liao (2004:473-77) that the reconstructions *si=dá $+*^{*}$ si NP and *ni=dá + *ni NP discussed above are themselves developments of earlier devices for marking plurality in the parent of the Philippine languages. Evidence for this will appear in Reid (to appear b).

2.2.4 Summary. The third option outlined above, then, is most widely supported in the Philippines and requires the fewest number of independent changes in the daughter

\section{FIGURE 3. INNOVATIONS}

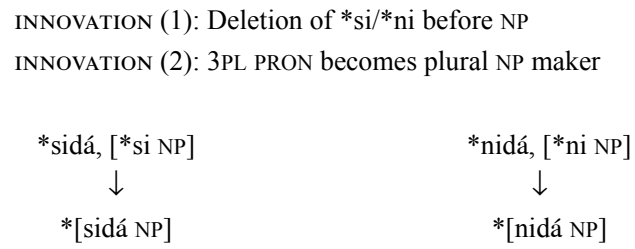

INNOVATION (3): Loss of unstressed initial syllable

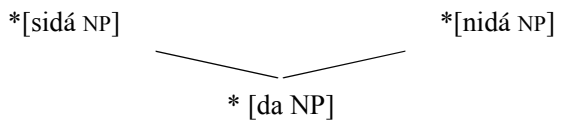


languages of the family. It also accounts for the plural personal noun marking of Kapampangan, one of the Central Luzon group of Northern Philippine languages (Forman I97I:52). If one similarly examines the languages that have a reflex of *na as a marker of genitive singular common NPs (as opposed to plural personal NPs), the argument becomes increasingly strengthened because, if Blust is right, one would need to assume that, in addition to the independent development of plural marking of the type discussed above in each of the subgroups in which it appears, it would be necessary to postulate the independent development of *na from a marker of plural personal genitive phrases to singular common noun phrases in a wide variety of Philippines languages, including Tagalog, Mamanwa, the Bisayan dialects spoken on Surigao, the Subanen languages, languages in each of the subgroups of Northern Luzon, as well as in a number of Formosan languages such as Kavalan, a sister language of Amis within the East Formosan subgroup, and Mayrinax Atayal, languages that formed the basis of the PAN *na / *ni ‘common noun / personal noun' reconstructions proposed in Pawley and Reid (I979).

3. THE FORMOSAN EVIDENCE. In order to evaluate the Blust hypothesis that *na was the PAN form that introduced genitive plural personal NPs, we now examine the data from the East Formosan languages that are available, as outlined in Blust (I999a:43).

3.1 EAST FORMOSAN LANGUAGES. We begin by examining the evidence from Amis, the various dialects of which constitute the Central branch. The forms will then be compared with available data from the languages of the Northern branch of the family, Kavalan and Basay-Trobiawan, and finally with Siraya, the only known language of the Southwest branch.

3.1.1 Amis. Although the dialects of Amis are fairly widely distributed along the east coast of Taiwan, the published literature does not indicate any differences between the forms that introduce noun phrases in the different dialects. These are presented in table 3 , using case-marking terminology that corresponds to that given in earlier tables in this paper. In the Amis sources (as also in Ross 2006), an unmarked noun phrase is sometimes labeled as bearing "neutral case." These are noun phrases that typically occur either as prepredicate topics, or as predicative nominals. Proper nouns, which in the sources are labeled as either oblique or accusative, I consider to be locatively marked and treat as such in the table for two reasons. One is because of the locative suffix -an which appears on personal nouns in this position, and the other is because, at least at earlier stages of the language, oblique forms (like those in Philippine languages) were probably indefinite and were restricted to common noun exponence. Forms with an $o$-vowel in the sources

\section{TABLE 3. NOUN PHRASE MARKERS IN AMIS ${ }^{\dagger}$}

$\begin{array}{lllllll} & & \text { UNM } & \text { NOM } & \text { GEN } & \text { OBL } & \text { LOC } \\ \text { COMMON } & & \mathrm{u} & \mathrm{ku} & \mathrm{nu} & \text { tu } & \mathrm{i} \\ \text { PERSONAL } & \text { SG } & \mathrm{ci} & \mathrm{ci} & \mathrm{ni} & & \text { ci N-an } \\ & \text { PL } & \mathrm{ca} & \mathrm{ca} & \text { na } & & \text { ca N-an }\end{array}$

$\dagger \quad$ Adapted from Tsukida (I993:379), Huang (I995:226), Li (I997:370), and Liu (I999:35); Fey's (I986) dictionary of Amis was not available to me at the time of writing. 
are represented here with an $u$-vowel, because Amis does not have a contrast between $u$ and $o$, and the vowel is a regular reflex of PAN *u.

The question that needs to be asked with reference to these data is to what extent we can determine that the forms, particularly those that mark genitive common and proper NPs, are unchanged reflexes of Proto-Austronesian noun phrase marking, or are the result of innovations that have resulted in the apparent convergence of form and function with similar forms in a few of the Philippine languages. We will approach this question in the same way as we did when examining the Philippine data, by attempting to determine what changes may have taken place in the system based on internal evidence, and by comparing the results with forms from related languages within and outside the East Formosan subgroup.

The reflex of PAN *s is Amis $c$ (Li I978, Blust I999a), so that the Amis singular and plural forms, respectively $c i$ and $c a$, appear to be regular reflexes of *si and *sa, as in table 4, making them formal cognates of the forms for marking singular and plural personal nouns in Philippine languages such as Ivatan, although the functions are not identical in that Amis $c i$ and $c a$ introduce not only topic, predicative, and nominative personal NPs, but also locative NPs, which in Ivatan are introduced by $d i$.

We noted in section 2 that Ivatan $s a$ is a monosyllabic variant of the reflex of the third person plural pronoun * $\mathrm{si}=\mathrm{da}$, but there is no evidence that this is the source of the preAmis *sa, because today the (unmarked) Amis third person plural pronoun is canra (Huang I995:236), ${ }^{14}$ from a pre-Amis *sa=yza. A comparison of the reconstructable preAmis third person pronouns shown in table 5 with the demonstrative forms shown in table 6 reveals that Amis $r a$ is a distal demonstrative base, cliticized to both singular and plural pronoun forms and is therefore not relatable to Ivatan $=r a$ (Huang I995:240). The Pre-Amis reconstructible demonstrative bases are given in table 7. An explanation for the development of these forms will be provided below.

TABLE 4. PRE-AMIS NOUN PHRASE MARKERS

\begin{tabular}{|c|c|c|c|c|c|c|}
\hline & & UNM & NOM & GEN & OBL & LOC \\
\hline COMMON & & $* u$ & ${ }^{*} \mathrm{ku}$ & $*$ nu & $* t u$ & $*_{\mathrm{i}}$ \\
\hline \multirow[t]{2}{*}{ PERSONAL } & SG & $*$ si & $*$ si & $*$ ni & & $*^{*}$ si N-an \\
\hline & PL & $*_{\mathrm{sa}}$ & $*$ sa & $*$ na & & *sa N-an \\
\hline
\end{tabular}

TABLE 5. PRE-AMIS THIRD PERSON PRONOUNS

$\begin{array}{lll} & \text { UNM } & \text { GEN } \\ \text { 3SG } & \text { *siyza } & \text { *ninza/*niza } \\ \text { 3PL } & \text { *sayza } & \text { *nayza }\end{array}$

TABLE 6. DEMONSTRATIVE FORMS IN AMIS ${ }^{\dagger}$

$\begin{array}{lllll} & \mathrm{NOM} & \mathrm{GEN} & \mathrm{OBL} & \text { LOC } \\ \text { PROXIMAL } & \mathrm{ku}=\mathrm{ni} & \mathrm{nu}=\mathrm{ni} & \mathrm{tu}=\mathrm{ni} & \text { tuni-an } \\ \text { DISTAL } & \mathrm{ku}=\mathrm{ra} & \mathrm{nu}=\mathrm{ra} & \mathrm{tu}=\mathrm{ra} & \text { tura-an } \\ \text { INVISIBLE } & \mathrm{ku}=\mathrm{ya} & \mathrm{nu}=\mathrm{ya} & \mathrm{tu}=\mathrm{ya} & \text { tuya-an }\end{array}$

$\uparrow \quad$ Adapted from Huang 1995:240.

I4. The Sakizaya Amis $u h n i$ 'unmarked $3^{\text {rd }}$ plural pronoun' appears to be completely unrelated and has an obscure source (Tsukida I993:383). 
Although none of the sources suggests that a demonstrative base can be attached to a personal noun marker to form a demonstrative pronoun that can refer to known individuals, the form nara appears in one of the examples in Tsukida's description of Sakizaya Amis in (I). However, this form is probably a borrowing from one of the other Amis dialects in which the reflex of *za is $r a$. The expected Sakizaya form would be **naza.

Tsukida notes that the proximal forms given as alternates (following the slash mark) in the first row of table 8 function only as demonstrative adjectives and occur directly preceding their head noun, without any intervening ligature. Each of the other forms in the first two rows of table 8 has the potential of appearing independently as a demonstrative pronoun, and can also function as a demonstrative adjective, occurring before a noun with or without an intervening $a$-ligature. Tsukida ( I993:384) thinks that the ina-forms developed from the sequence of demonstrative plus ligature, $i n i+a$, because a ligature optionally occurs following adjectival demonstratives ending in ini, but never when the form is ina.

A similar set of forms, all with $i$-vocalism, is found in the data given in Chen's (I987) description of Nataoran Amis (see table IO), none of which apparently occurs cliticized to a form with $u$-vocalism, as occurs in Sakizaya.

(I) SAKIZAYA AMIS Ayzato o mikatanektekan to nara ko nikaozip noniam. now already PRED stable already GEN.3P NOM life GEN.IP.EXCL 'Now, our life became stable because of them.'

(lit. 'Our life is already a thing which was made stable by them.')

\section{TABLE 7. PRE-AMIS DEMONSTRATIVE BASES}

$\begin{array}{ll}\text { PROXIMAL } & *_{\text {ni }} \\ \text { DISTAL } & *_{\text {za }} \\ \text { INVISIBLE } & * \text { ya }\end{array}$

TABLE 8. DEMONSTRATIVE FORMS IN SAKIZAYA AMIS

$\begin{array}{lllll} & \text { UNM } & \text { NOM } & \text { GEN } & \text { OBL } \\ \text { 'this one' } & \text { u=(i)ni / } & \text { ku=(i)ni / } & \text { nu=ni / } & \text { tu=(i)ni / } \\ & \text { ina } & \text { kina } & \text { ku)=nina } & \text { tina } \\ \text { 'that one' } & \text { u=iza } & \text { ku=iza } & \text { nu=iza } & \text { tu=iza } \\ \text { 'definite' } & \text { iya } & \text { kiya } & (n)=\text { niya } & \text { tiya }\end{array}$

$\uparrow \quad$ Adapted from Tsukida I993:384.

TABLE 9. PRE-SAKIZAYA AMIS DEMONSTRATIVE BASES

$\begin{array}{ll}\text { PROXIMAL } & * \text { ini / *ina } \\ \text { DISTAL } & *_{\text {iza }} \\ \text { DEFINITE } & * \text { iya }\end{array}$

TABLE 10. DEMONSTRATIVE FORMS IN NATAORAN AMIS ${ }^{\dagger}$

$\begin{array}{llllll} & \text { UNM } & \text { NOM } & \text { GEN } & \text { OBL } & \text { LOC } \\ \text { PROXIMAL } & \text { ina } & \text { kina } & \text { nina } & \text { tina } & \text { itina } \\ \text {-REMOTE } & \text { ia } & \text { kia } & \text { nia } & \text { tia } & \text { itia } \\ \text { +REMOTE } & \text { ira } & \text { kira } & \text { nira } & \text { tira } & \text { itira }\end{array}$

$\dagger \quad$ Adapted from Chen I987:I27. 
Tsukida's description of Sakizaya Amis also provides further insights into developments that have taken place in at least that dialect of the group. While Sakizaya Amis directly reflects the forms reconstructed in table 4 , with all common noun markers (except locative) having an $u$-vowel, all singular personal noun markers having an $i$-vowel, and plural personal noun markers having an $a$-vowel, the vocalism is different when the markers have cliticized demonstratives attached. Tsukida treats the common noun markers that occur without any attached reflex of a demonstrative base as conveying a generic sense. Definite common nouns are marked by forms with $i$-vocalism and the clitic $=y a$ attached, as in table 8. Other forms with attached demonstrative bases were also apparently originally attached to $i$, forming a reconstructible series, shown in table 9.

The general principle that must be applied in a situation such as this is that 'inner is older, outer is newer'. For Proto-Amis, then, it is necessary to reconstruct a system in which the vocalism of generic common noun markers was *i and probably closely resembled the system reconstructed as table I I. This immediately calls into question the validity of Blust's reconstruction of genitive marking that proposes PAN *nu as the marker of genitive common nouns (and also Ross's [2006:547] reconstruction of Proto-Amis forms with *u-vocalism). That *nu may have occurred as one of the possible forms that marked such nouns is possible, but its function is controversial, and will be addressed below.

Apart from the demonstratives with $i$-vocalism, Amis maintains several frozen forms ending in $=y$ that imply the presence of $* i$ as an unmarked generic specifier at some earlier stage of the language. These include inay 'negative existential' as in (2a), ${ }^{15}$ and izay 'why', as in (2b).

(2) SAKIZAYA AMIS

$$
\begin{aligned}
& \text { a. ... inay ko sapisakakawaw. } \\
& \text { there.is.not NOM will.to.work } \\
& \text { '... there is no will to work.' }
\end{aligned}
$$

b. Izay ha moagic kina wawa?

why HA cry NOM.this child

'Why is this child crying?'

To summarize, considering the range of marking found in the various Amis dialects, we find no support for the claim that Amis $n u$ directly reflects a proposed PAN *nu 'genitive singular common noun marker', in contrast to a PAN *na 'genitive plural personal noun marker'. But can we find an explanation for the presence of $n a$ with this function in

\begin{tabular}{|c|c|c|c|c|c|}
\hline & UNM & NOM & GEN & OBL & LOC \\
\hline GENERIC & $*_{\mathrm{i}}$ & *ki & *ni & $* \mathrm{ti}$ & $*_{\mathrm{i}}$ \\
\hline PROXIMAL & $*_{\text {ina } / * \text { ini }}$ & *kina / *kini & *nina & 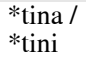 & $*_{i}$ tina $/ *_{i}$ tina \\
\hline -REMOTE & *iya & *kiya & *niya & $*$ tiya & $*_{\text {i tiya }}$ \\
\hline +REMOTE & *iza & *kiza & *niza & $*$ tiza & $*_{\mathrm{i}}$ tiza \\
\hline
\end{tabular}
Amis? I believe we can.

\section{TABLE 11. PROTO-AMIS COMMON NOUN MARKING}

I5. Compare with various Philippine languages that also maintain an old nominative *=y clitic on some vowel-final existential forms, such as Bontok wad-ay 'there is'. 
Table I 2 displays a summary of Amis personal pronouns. Of particular interest here are the genitive forms, nira 'genitive 3rd person singular pronoun', niyam 'genitive Ist person exclusive plural pronoun', пати 'genitive 2nd person plural pronoun', and nayra 'genitive 3rd person plural pronoun'. It was noted above that nira is a compound of the genitive personal noun marker $n i$ and a distal demonstrative form $=r a(<*$ za). The presence of $n i$ also on the plural form niyam suggests that $n i$ was not restricted as a marker of singular genitive pronouns, but could also mark genitive plural pronouns as well. The form пати apparently developed from a Proto-Amis sequence of *ni=amu, with loss of the $i$-vowel in the same way as described by Tsukida (I993:384) for the development of the demonstrative-ligature sequence *ini=a as Sakizaya Amis ina 'this'. A similar sequence of developments is found in the pronominal systems of some Philippine languages such as Tagalog, where *ni + *2amən $>* *$ ni=amən $>$ TAG námin 'genitive Ist person exclusive plural pronoun', and *ni $+*$ Ratən $>* *$ ni=atən $>$ TAG nátin 'genitive Ist person inclusive plural pronoun', and in Cebuano where *ni $+*$ ?amən $>* *$ ni=amən $>$ Ceb namo 'genitive Ist person exclusive plural pronoun', and *ni + *2atən $>* *$ ni=atən $>$ Ceb nato (compare Bikol nyamo and nyato, which did not undergo vowel loss).

Proto-Austronesian probably did not have any third person personal pronouns, so that their presence in the daughter languages in Formosa and the Philippines is the result of independent innovations in a number of subgroups. In Amis, it appears that the third person singular form was a case-marked distal demonstrative *niza. This became the base for the third person plural form by reduplicating it with ${ }^{*} \mathrm{C}_{\mathrm{I}} \mathrm{a}$-, to produce $* *$ naniza, and ultimately by vowel loss and dissimilation, *nayza. Although this function of $* \mathrm{C}_{\mathrm{I}} \mathrm{a}$ - has not previously been documented, it can clearly be seen as an extension of one of the functions described by Blust (1998, I999b:I69): "it was used to form numerals that referred distinctively to human beings." Here it is being used to form a plural demonstrative pronoun that referred distinctively to human beings.

I claim that it was the presence of the sequence $n a$ - at the beginning of three of the plural pronouns that allowed it to be reanalyzed as a marker also for genitive plural nouns, establishing a *ni / *na 'singular/plural' contrast, and allowing the back formation *ninza to be developed as an alternate genitive third person singular pronoun. The sequence *=yza spread also to the unmarked pronouns, forming a singular form encliticized to *si. $A$-vocalism became associated with plural marking, and the third person plural pronoun *sayza resulted, with *sa becoming the form that also introduced unmarked plural NPs. If

TABLE 12. AMIS PERSONAL PRONOUNS ${ }^{\dagger}$

$\begin{array}{lllll} & \text { NOM } & \text { GEN } & \text { POS } & \text { OBL/LOC } \\ \text { IS } & \text { kaku } & \text { aku } & \text { maku } & \text { takuwanan } \\ \text { 2S } & \text { kisu } & \text { isu } & \text { misu } & \text { tisuwanan } \\ \text { 3S } & \text { cinra } & \text { nira, nipra } & \text { nipra, nira } & \text { cinraan, cinranan } \\ \text { IP.INCL } & \text { kita } & \text { ita } & \text { mita } & \begin{array}{l}\text { kitanan, kitaanan } \\ \text { titanan, titaanan }\end{array} \\ \text { IP.EXCL } & \text { kami } & \text { niyam } & \text { niyam } & \text { tamiyanan } \\ \text { 2P } & \text { kamu } & \text { namu } & \text { namu } & \text { tamuanan, tamuwanan } \\ \text { 3P } & \text { cayra } & \text { nayra } & \text { nayra } & \text { canraan, canranan }\end{array}$

From Liu I999:3I. 
this analysis is correct, Ivatan sa '3rd person plural pronoun', which alternates with sira, has a different source from the initial CV of *sayza. The forms - though identical in form and meaning — are not cognate.

3.1.2 Kavalan. We now look beyond the Amis dialects to other members of the East Formosan subgroup to find any evidence in support of the claims made in the previous section. First we will examine the data that are available for Kavalan. Table I3 displays the forms that introduce NPs. We immediately note that genitive NPs distinguish singular from plural personal nouns in the same way that Amis does, with na marking plural personal nouns. But in Kavalan the same form also marks singular common nouns, as shown in $(3 \mathrm{a}-\mathrm{c})$ and $(4 \mathrm{a}-\mathrm{b})$. Comparison with the Kavalan short genitive pronouns presented in table $\mathrm{I} 4$ is instructive.

While Amis developed its third person singular pronoun by cliticizing the demonstrative base *za to the genitive personal noun marker *ni, and apparently reduplicated it to form the third person plural pronoun, Kavalan developed its third person pronoun from the demonstrative *na, and added a pluralizing form following it to create its third person plural pronoun. ${ }^{16}$ Long genitive forms have all been re-formed in Kavalan, by encliticizing each of the short genitive forms to the demonstrative base $z a$, as in table 15 . That this has been an independent process from what has occurred in Amis is evident from the third person forms, which show the reverse order of the two elements, KAV $z a=n a$ 'genitive 3S/P' vs. AMI $n a=r a$ 'genitive 3P'.

TABLE 13. NOUN PHRASE MARKERS IN KAVALAN ${ }^{\dagger}$

$\begin{array}{lllllll} & & \text { UNM } & \text { GEN } & \text { OBL } & \text { LOC I } & \text { LOC 2 [+DIR] } \\ \text { COMMON } & & \text { a } & \text { na } & \text { tu, ta } & \text { ta ...-an } & \text { sa } \\ \text { PERSONAL } & \text { SG } & \text { ti / a } & \text { ni } & & & \\ & \text { PL } & & \text { na } & & \end{array}$

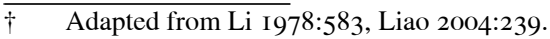

TABLE 14. KAVALAN SHORT FORM GENITIVE PERSONAL PRONOUNS

\begin{tabular}{ll} 
IS & $=\mathrm{ku}$ \\
& \\
$2 \mathrm{~S}$ & $=\mathrm{su}$ \\
$3 \mathrm{~S}$ & $=\mathrm{na}$ \\
\hline$\dagger$ & Adapted from Li I996:589.
\end{tabular}

$\begin{array}{ll}\text { IP.INCL } & =\text { ta } \\ \text { IP.EXCL } & =\text { nyaq } \\ 2 P & =\text { numi } \\ 3 P & \text { na qanyau }\end{array}$

TABLE 15. KAVALAN LONG FORM GENITIVE PERSONAL PRONOUNS

\begin{tabular}{lc} 
IS & zaku \\
& \\
$2 S$ & zasu \\
$3 S$ & zana \\
\hline$\dagger$ & Adapted from Li I $996: 589$.
\end{tabular}

$\begin{array}{ll}\text { IP.INCL } & \text { Zata } \\ \text { IP.EXCL } & \text { zanyaq } \\ \text { 2P } & \text { zanumi } \\ 3 \text { PP } & \text { zana qanyau }\end{array}$

I6. Kavalan has also developed third person agreement marking for agents on the verb by fusing the pronoun with the suffix -an to form a verb-ending -ana, as in (4a-b), in precisely the same way that has developed in many of the Northern Luzon languages (Reid 200I, Liao 2002). 
(3) KAVALAN

a. saquLusan na sunis=na

(Li I978:583, 586, 59I)

clothes GEN child=GEN.3SG

'her child's clothes'

b. tanman na Lazat a wasu?

buried GEN man NOM dog

'The dog was buried by the man.'

c. msaRaq a tiwtay tu zana tama=na?

brewed.wine NOM Tiwtay OBL GEN.3SG father=GEN.3SG

'Tiwtay brewed wine for his father.'

(4) KAVALAN

(Liao 2002:2 I7, 250)

a. Taktakana ya taqan na repaw na bayblan.

cut.down.?3SG/PL NOM pillar GEN house GEN old.woman

'They cut down the pillar(s) of the old woman's house.' (Kav.8-02 I)

b. Inebana=ti na hetay a rawang.

close.?3SG/PP=PRF GEN soldier NOM city

'The soldiers closed the city (gate).'

(Kav.7-033)

We are left, then, with the conclusion that while the Kavalan genitive third person pronoun and genitive third person plural personal noun marker developed from the same source, it is probably different from what has occurred in Amis (and also from what has occurred in Philippine languages), so that it would not be appropriate to reconstruct *na for the latter function, even for Proto-East Formosan, let alone Proto-Austronesian. Furthermore, Kavalan provides no evidence for either *ni or *nu as a genitive common noun marker, in that nominative, genitive, and locative common noun markers all have $a$ vocalism. Only the oblique form $t u$ is shared between the two languages, and that has been shown to be probably a secondary development, at least in Amis, from an earlier form with an $i$-vowel. The $u$-vowel in the genitive second plural pronoun =numi must be an analogical development based on the vocalism of the genitive second singular pronoun $=s u$, since $n u$ is nowhere claimed to be a marker of personal nouns (or pronouns).

3.1.3 Basay. Data for Basay and its related dialect Trobiawan, now extinct languages, are scarce, but we are fortunate to have careful analyses of the extant data in various works by Li (I996, I999, 2004, etc.). Table I6 presents the forms that introduce NPs with common nouns. None of the published data have sentences with personal noun phrases, so evidence here is lacking. We do note, however, that the form na appears in the data, but only with an aspectual meaning 'already', as found in many Philippine languages such as Tagalog. The form $n u$ does not appear among the noun phrase markers, but $s u$ and $u$ appear as oblique common noun markers, depending on the dialect. We get no help from

\section{TABLE 16. BASAY COMMON NOUN PHRASE MARKERS ${ }^{\dagger}$}

\begin{tabular}{|c|c|c|c|}
\hline NOM & OBL & LOCI & LOC2 \\
\hline$a^{\ddagger}$ & $\mathrm{su}^{\dagger \dagger}$ & li $(<* d i)$ & ta \\
\hline
\end{tabular}


the pronouns. The third person form, $y a,{ }^{17}$ has been adopted in this language for this function, and Li notes that "there is generally no distinction between singular and plural genitives for the third person in Basay" (I999:644).

3.1.4 Siraya. Finally we turn to the southwestern member of the East Formosan group, Siraya, also an extinct language. Table I 7 provides a list of forms that introduce noun phrases. These are referred to by Adelaar (I997:375) as forms that mark grammatical relations. There are no markers listed for plural personal nouns, and even the singular personal noun marking has undergone innovation, with ti replacing the earlier unmarked and genitive forms *si and *ni, respectively. The source of the locative marker tu may also be from an earlier oblique *su, reflected in Basay (as well as in Ivatan and some other Philippine languages).

While there is no evidence from the forms that precede personal nouns to support the reconstruction of *na 'genitive plural personal noun marker', the form na does occur. Adelaar notes that "the exact meaning and function of na needs further investigation. It precedes nominals and usually seems to make them definite. ... in some cases it seems to suggest a source relation (Genitive)" (Adelaar I997:374).

Is there any evidence from the pronouns that might indicate an earlier *na 'genitive plural personal noun marker'? In fact, there is. While other members of the East Formosan family have enlisted one of the demonstratives *za or *ya for their third person pronoun, Siraya appears to have enlisted the demonstrative *ini (see table I8). This form became cliticized to the nominative common noun marker *ta, with the sequence *ai becoming $e$. A similar explanation is available for the plural form, if one assumes that in this case *ini became cliticized to a plural personal noun marker *na, with assimilation raising * a to $e$ before the following $i$-vowel. We are left, however, with the problem that $n a$ is attached to all third person plural pronouns, not just genitives, and that the plural pronouns on which it appears are clearly the result of local developments. We may assume, without further data, that na in this function may have been borrowed from Kavalan or Amis, originally as a genitive plural pronoun marker, and then spread to other pronouns.

TABLE 17. SIRAYA NOUN PHRASE MARKERS ${ }^{\dagger}$

$\begin{array}{llll} & \mathrm{NOM}^{\ddagger} & \text { GEN/OBL } & \text { LOC } \\ \text { COMMON } & \text { ta } & \mathrm{ki}^{\dagger \dagger} & \text { tu } \\ \text { PERSONAL } & \text { ta ti } & \text { ti } & \text { ti ...-an }\end{array}$

Adapted from Adelaar I997:374, Tsuchida 2000: I I 2, fn. 7.

\$ Adelaar labels this grammatical function as 'Topic'.

$+\dagger$ Tsuchida notes that "an oblique case marker $k i$ indicates any relations other than nominative and locative relations, so that it can indicate an object or instrumental/comitative 'with, together', etc., in a verb phrase, or a genitive 'of' in a noun phrase."

TABLE 18. SIRAYA THIRD PERSON PRONOUNS

$\begin{array}{llll} & \text { UNM } & \text { NOM } & \text { GEN } \\ 3 \mathrm{~S} & \text { teni } & \text { teni } & \text { tim } \\ 3 \mathrm{P} & \text { ta neini } & \text { neini } & \text { nein }\end{array}$

Adapted from Adelaar I997:373.

I7. This form is represented by $\mathrm{Li}$ as $i a$. 
3.2 OTHER FORMOSAN LANGUAGE EVIDENCE. A quick survey of noun phrase marking forms in some other Formosan languages enables us to draw the following conclusions regarding Blust's proposed reconstructions, specifically (i) PAN *na 'genitive plural personal noun marker' and (ii) PAN *nu 'genitive common noun phrase marker'.

There are no languages other than Amis that uniquely reflect *na with the proposed function. However the form is reflected, as it is in many Philippine languages, as one of the common noun markers, oblique in Tona Rukai (Li 1997:360), nominative in Tsou (Li 1997:35I), nonreferential (generic) genitive and instrumental in Mayrinax and Squliq Atayal (Huang I995:I09, Li 1997:347, Liao 2004:325), and genitive in Paiwan (Li 1997:366). Assigning a plural personal noun marking function to PAN *na would require us to assume that convergent development, from plural personal noun marking to singular common noun marking, took place in the parent of each of the first order subgroups represented, as well as in Kavalan and Amis of the East Formosan group.

The reflexes of PAN *nu always appear as one of the common noun markers, oblique in Tsou (Li 1997:35I), or genitive in Saisiyat, Paiwan, and Pazeh (Li 1997:366, 372), providing significant support for at least this portion of Blust's proposal, and are in line with my reconstruction of both *na and *nu common noun phrase markers (Reid I978, I979, I98I).

4. CONCLUSION. In critiquing his own earlier reconstruction of *ni as a marker of genitive common noun phrases, ${ }^{18}$ Blust concludes that despite the straightforward evidence that he used to make the reconstruction, "there seems to be little reason to doubt that the evidence ... is a product of convergence, although one that is uncommonly striking" (Blust 2005:22I). In fact, it appears that convergence of form and function of the type discussed is a rather common process in Austronesian languages. There is clear evidence that *na needs to be reconstructed as a demonstrative for Proto-Austronesian, and is probably the source of the ubiquitous ligature *na occurring between heads and dependents in many Formosan and Philippine languages. In addition, it was the source of some third person singular personal pronouns, and also became a nominal specifier, marking definiteness or specificity of a following noun. But *na in some functions apparently developed from other sources as well. As the Sakizaya Amis data suggest, the demonstrative ina developed from the sequence of a demonstrative ini plus ligature $a$. By the same process, the sequence $n a$ - also developed at the beginning of $a$-initial pronouns that were earlier marked by $n i$, while, at the beginning of a third person plural pronoun, it may also have developed from $\mathrm{C}_{\mathrm{l}} a$ - reduplication of a $n$-initial form. Genitive third person plural pronouns beginning with $n a$ - could also have formed an analogical base for the development of $n a$ as a marker of genitive plural personal noun phrases. The Philippine evidence likewise suggests alternative sources for $n a$, one of which is what I have been calling "vowel-grade harmony," by which a process of long-distance vowel harmony operates across syntactic boundaries within a clause, resulting in sequences of phrases having markers with the same vocalism. 
Where does this leave us? Pretty much back where we were in the I970s. We are left with the conundrum of why some languages use reflexes of *nu to mark genitive common noun phrases, and why some use reflexes of *na for the same function. Ross (2006:53I) notes that "on typological grounds, one might expect the *-a/*-u distinction in PAn common case-markers to encode a \pm definite or \pm specific distinction. There is miniscule evidence for such a distinction in the Atayal ... and Rukai ... data, but it is too scant to build a case on, and so the puzzle remains." The problem may lie in Ross's analysis of the initial nasal of PAN *nu as a case marker, and the assumption that this form commuted with *na in PAN to mark genitive common noun phrases, when there seems to be clear evidence (discussed in Reid I98I:IO2-4) that *nu was probably not a case marker at all, but a nonreferential noun 'thing' that formed the base of a wide range of interrogative words, such as those in table I9 (cf. Dempwolff's *anu and Dahl's *an ${ }_{\mathrm{I}} \mathrm{u}$ 'somebody, something').

As a noun, *nu was not itself case-marked and could be followed by a genitive NP ('thing of the man', etc.) and could have genitive clitics attached to it to signify nouns of absolute possession, as in Amis nu=maku 'mine, lit. my thing', $n u=m i s u$ 'yours (SG)', $n u=n i a m$ 'ours (INCL), nu=mita 'ours (EXCL)', etc. It could also be followed by a linked nominal construction, *nu+a N, as in Paiwan nua N. Subsequent changes brought about a shift from nonreferential noun to case marker, resulting in *nu becoming a marker of genitive constructions, with the semantic reference being assigned independently in each family where this occurred to distinguish it from the other *n-initial genitive markers.

Much more work needs to be done on bottom-up reconstruction to discern the actual historical developments that have brought about the plethora of forms that we find, the semantic shifts that the demonstratives have undergone, and the grammaticalization processes in which they have been involved before we can be sure that the forms and functions we find in today's languages are not the result of convergent development but are true reflexes of reconstructed protoforms.

TABLE 19. FORMOSAN INTERROGATIVES BASED ON REFLEXES OF PAN *nu ${ }^{\dagger}$

\begin{tabular}{lll} 
Squliq Atayal & na-nu? & 'what' \\
i-nu & 'where' \\
Sediq & ma-nu? & 'what' \\
& ?i-nu? & 'where' \\
& ka-nu-wan & 'when' \\
Favorlang & nu-mma & 'what' \\
Thao & nu:-ma & 'what' \\
Saisiyat & ka-no? & 'what' \\
& hay-no? & 'where' \\
& ? i-no-wan & 'when (future)' \\
\hline$\dagger$ & From Ferrell I969.
\end{tabular}




\section{REFERENCES}

Adelaar, K. Alexander. I997. Grammar notes on Siraya, an extinct Formosan language. Oceanic Linguistics 36:362-97.

Blust, Robert A. I974. Proto-Austronesian syntax: The first step. Oceanic Linguistics I3: I-I5.

. I998. Ca- reduplication and Proto-Austronesian grammar. Oceanic Linguistics 37:29-64.

-. I999a. Subgrouping, circularity and extinction: Some issues in Austronesian comparative linguistics. In Selected Papers from the Eighth International Conference on Austronesian Linguistics, ed. by Elizabeth Zeitoun and Paul Jen Kuei Li, 3 I-94. Taipei: Academia Sinica.

- I 999b. A note on covert structure: $\mathrm{Ca}$ - reduplication in Amis. Oceanic Linguistics 38: $168-74$.

. 2005. A note on the history of genitive marking in Austronesian languages. Oceanic Linguistics 44:2 I 5-22.

Chen, Teresa M. I987. Verbal constructions and verbal classification in Nataoran-Amis. Canberra: Pacific Linguistics.

Daguman, Josephine S. 2004. A grammar of Northern Subanen. PhD diss., La Trobe University.

Fey, Virginia. 1986. Amis dictionary. Taiwan: The Bible Society in the Republic of China.

Forman, Michael L. I97I. Kapampangan grammar notes. PALI Language Texts: Philippines. Honolulu: University of Hawai' 'i Press.

Huang, Lillian M. I995. A study of Mayrinax syntax. Taipei: The Crane Publishing Co. Hussey, Jean. I966. Noun phrase markers in Aborlan Tagbanwa. In Papers in Philippine linguistics No. I, 33-38. Canberra: Pacific Linguistics.

Li, Paul Jen-Kuei. 1978. The case-marking systems of the four less-known Formosan languages. In Papers from the Second International Conference on Austronesian Linguistics, fasc. I: Western Austronesian, ed. by S. A. Wurm and Lois Carrington, 569-6 I5. Canberra: Pacific Linguistics.

. I996. The Formosan tribes and languages in I-Lan. Monograph Series of I-Lan History: Linguistics I. I-Lan, Taiwan: I-Lan Prefecture Government.

- I997. A syntactic typology of Formosan languages: Case markers on nouns and pronouns. In Chinese languages and linguistics 4: Typological studies of languages in China, ed. by Chiu-yu Tseng, 343-78. Taipei: Academia Sinica.

- I999. Some problems in the Basay language. In Selected papers from the Eighth International Conference on Austronesian Linguistics, ed. by Elizabeth Zeitoun and Paul Jen-kuei Li, 637-65. Taipei: Academia Sinica.

. 2004. Origins of the East Formosan peoples: Basay, Kavalan, Amis and Siraya. Language and Linguistics 5(2): 363-76.

Liao, Hsiu-Chuan. 2002. The interpretation of $t u$ and Kavalan ergativity. Oceanic Linguistics 4I:I40-58.

. 2004. Transitivity and ergativity in Formosan and Philippine languages. $\mathrm{PhD}$ diss., University of Hawai 'i.

Liu, Dorinda Tsai-Hsiu. 1999. Cleft constructions in Amis. MA thesis, National Taiwan University.

Miller, Jeanne, and Helen Miller. I976. Mamanwa grammar. Language Data: AsianPacific Series No. 8. Huntington Beach, CA: Summer Institute of Linguistics.

Mintz, Malcolm W. I97I. Bikol grammar notes. PALI Language Texts: Philippines. Honolulu: University of Hawai'i Press. 
Pawley, Andrew, and Lawrence A. Reid. I979. The evolution of transitive constructions in Austronesian. In Austronesian Studies: Papers from the Second Eastern Conference on Austronesian Languages, ed. by Paz Buenaventura Naylor, I03-30. Ann Arbor: Center for South and Southeast Asian Studies, The University of Michigan.

Reid, Lawrence A. I978. Problems in the reconstruction of Proto-Philippine construction markers. In Second International Conference on Austronesian Linguistics: Proceedings, vol. I, ed. by S. A. Wurm and Lois Carrington, 33-66. Canberra: Pacific Linguistics.

- I979. Evidence for Proto-Philippine nominative marking. Philippine Journal of Linguistics IO(I-2): I-20.

- I98I. Proto-Austronesian genitive determiners. In Linguistics across continents: Studies in honor of Richard S. Pittman, ed. by Andrew B. Gonzalez and David Thomas, 97-I05. Manila: Summer Institute of Linguistics and Linguistic Society of the Philippines.

- 200I. On the development of agreement markers in some Northern Philippine languages. In Issues in Austronesian morphology: A focusschrift for Byron W. Bender, ed. by Joel Bradshaw and Kenneth L. Rehg, 235-57. Canberra: Pacific Linguistics.

- 2002. Determiners, nouns or what? Problems in the analysis of some commonly occurring forms in Philippine languages. Oceanic Linguistics 4I:295-309.

- 2006. On the origin of the Philippine vowel grades. Oceanic Linguistics 45:457-73.

. To appear a. On reconstructing the morphosyntax of Proto-Northern Luzon. Philippine Journal of Linguistics.

- To appear b. Inclusory pronoun constructions in Philippine languages. In To be announced, ed. by Sander Adelaar and Andrew Pawley. Canberra: Australian National University.

Reid, Lawrence A., and Hsiu-Chuan Liao. 2004. A brief syntactic typology of Philippine languages. Language and Linguistics 5(2): 433-90.

Ross, Malcolm. 2006. Reconstructing the case-marking and personal pronoun systems of Proto Austronesian. In Streams converging into an ocean: Festschrift in honor of Professor Paul Jen-Kuei Li on his 7oth birthday, ed. by Henry Y. Chang, Lillian M. Huang, and Dah-an Ho, 52 I-63. Taipei: Academia Sinica.

Schachter, Paul, and Fe T. Otanes. I972. Tagalog reference grammar. Berkeley: University of California Press.

Tsuchida, Shigeru. 2000. Lexical prefixes and prefix harmony in Siraya. In Grammatical analysis: Morphology, syntax, and semantics: Studies in honor of Stanley Starosta, ed. by Videa P. De Guzman and Byron W. Bender, I09-28. Honolulu: University of Hawai'i Press.

Tsukida, Naomi. I993. A brief sketch of the Sakizaya dialect of Amis. Tokyo University Linguistics Papers 13:375-4I3.

Wu, Jing-Lan Joy. 2006. Verb classification, case marking, and grammatical relations in Amis. PhD diss., State University of New York at Buffalo.

Yamada, Yukihiro, and Shigeru Tsuchida. 1975. Philippine languages. Asian and African Grammatical Manual No. I5b. Tokyo: Institute for the Study of Languages and Cultures of Asia and Africa, Tokyo University of Foreign Studies.

Zorc, R. David Paul. I977. The Bisayan dialects of the Philippines: Subgrouping and reconstruction. Canberra: Pacific Linguistics. 